\title{
Use of ICT-based teaching aids with the RME approach to developing Understanding Ability and Communication and Mathematical Disposition of Primary School Students
}

\author{
Siti Chotimah ${ }^{1}$, Martin Bernard ${ }^{2}$, Asep Ikin Sugandi ${ }^{3}$, Risma Amelia ${ }^{4}$ \\ \{chotimahchotie@gmail.com ${ }^{1}$, pmartinernard@gmail.com², asepikinsugandi@gmail.com ${ }^{3}$ \} \\ IKIP Siliwangi, Bandung Indonesia
}

\begin{abstract}
This study aims to examine in depth the effect of the RME approach on students' understanding and communication abilities and mathematical dispositions compared to ordinary learning. This research is an experiment with pretest-posttest control group design. The population in this study were all third-grade elementary school students in West Bandung, while the sample was third-grade students from one elementary school in West Bandung Regency which was determined purposively. The research data will be analyzed using statistical test $t$, contingency coefficient test and test with statistics. The instrument used in this study is a test of mathematical understanding and communication skills and students' mathematical dispositions. Based on quantitative data analysis, it was concluded that: there was an achievement of the ability of mathematical understanding of elementary school students who learned using the RME approach, there is the achievement of mathematical communication skills of elementary school students whose learning uses the RME approach, teaching using the RME approach influences students' mathematical dispositions, there is no association between the ability of mathematical understanding with students' mathematical communication skills, there is no association between mathematical dispositions with students' mathematical understanding abilities, and there is no association between mathematical dispositions with students' mathematical communication skills.
\end{abstract}

Keywords: Mathematical Understanding, Mathematical Communication, and Mathematics Disposition Ability

\section{Introduction}

Education in elementary schools is the beginning of a child knowing the world of formal education. Where a child at an early age has a high cognitive memory ability. In primary school-age children between 7 years and 12 years, the stage of thinking they tend to want to know and experiment. This is the basis, that in primary schools is the center of the main educational dynamics. Primary school age children are more sensitive and sharp in absorbing all their knowledge.

Mathematics is an important part that cannot be separated from human life. According to Sundayana (2014), mathematics is one component of a series of subjects that have an important role in education, mathematics is one of the fields of study that supports the 
development of science and technology. While the Ministry of National Education (Herlina, Turmudi, and Dahlan, 2012: 1) said, In the development of modern technology mathematics has an important role in developing the human mindset so that mathematics is used as a foundation. Mathematics provides students with the ability to think logically, analytically, systematically, critically, and the ability to cooperate. So that mathematics needs to be taught in schools, starting from elementary school to college.

But until now there are still many students who feel mathematics as a difficult, unpleasant subject, even a frightening specter. This is because there are still many students who experience difficulties in working on math problems. Johnson and Myklebust (Chotimah, 2015) suggest that Mathematics is a symbolic language that has a practical function to express quantitative and spatial relationships. While the theoretical function is to facilitate thinking. In other words, mathematics is a provision for students to think logically, analytically, systematically, critically, and creatively. As a symbolic language, the main characteristic of mathematics is deductive reasoning but does not ignore the method of inductive reasoning. Aside from being a symbolic language, mathematics is also a science whose object studies are abstract. Mathematics subjects need to be given to all students starting from elementary school to equip students with the ability to think logically, analytically, systematically, critically, and creatively, as well as the ability to cooperate, BNSP (2006).

Multiplication is one of the concepts in mathematics that was introduced in third-grade elementary school with the delivery technique is still very low. Multiplication counting technique that is still often taught in class is a way to memorize multiplication tables 1 to 10 . While for numbers whose size is above 10 still use multilevel multiplication techniques.

In NCTM (2000: 60) explains that, mathematics learning must provide opportunities for students to 1) organize and consolidate mathematical thoughts and ideas by communicating them; 2) communicating their mathematical thinking logically and clearly to friends, teachers, and others; 3) analyze and evaluate other people's mathematical thinking; 4) using mathematical language to express their ideas correctly.

Researchers want to foster and develop students' understanding and communication skills and mathematical dispositions with the RME approach. Researchers believe that with the RME approach students can succeed because the RME approach relates to the real world context. According to Kuiper \& Kuver (Suherman, 2003: 143), several preliminary studies in several countries show that learning uses a realistic approach, (1) mathematics is more interesting, relevant, and meaningful, not too formal and not too abstract; (2) consider the level of student ability; (3) emphasize learning mathematics on "learning by doing"; (4) facilitating the resolution of mathematical problems without using standard (algorithm) solutions; (5) using context as a starting point for mathematics learning.

Kilpatrick et al. (2001) argue that understanding concepts involves understanding mathematical ideas that are comprehensive and functional. Meanwhile, according to Skemp Sumarmo ( Hendriana and Soemarmo, 2014) classifies understanding abilities in two levels, (1) instrumental understanding: memorizing concepts/principles without regard to others, can apply formulas in algorithmic calculations. This ability is classified as a low-level ability; (2) relational understanding: linking one concept/principle with another concept/principle. This ability belongs to a high level of ability..

It can be said if a student has reached a deeper and meaningful understanding then the student can feel the benefits of mathematics in his life, where it is the goal and goal achieved. 
To get an understanding of learning mathematics, each material must be in accordance with the level or level of students' thinking. Understanding gained when learning mathematics is able to foster mathematical thinking skills. Mathematical thinking is what is needed to achieve the benefits of mathematics in everyday life.

According to Schoen, Bean, and Ziebarth (Chotimah, 2014: 14), mathematical communication is the ability of students to explain an algorithm and unique ways of solving problems, the ability of students to construct and explain the presentation of real-world phenomena in graphs, words / sentences, equations, table and physical presentation, students' ability to give guesses about geometric drawings. Communication skills in mathematics are the ability of students to read mathematical discourse with understanding, able to develop language and mathematical symbols so that they can communicate orally and in writing, able to visualize and reflect images or diagrams into mathematical ideas, able to formulate and solve problems through discovery..

Mathematical disposition according to Sumarmo (Amelia, 2015) is a strong desire, awareness, tendency, and dedication to students or students to think and act mathematically. Wardani (2008) defines a mathematical disposition as an attraction and appreciation for mathematics, namely the tendency to think and act positively, including self-confidence, curiosity, perseverance, enthusiasm in learning, persistent problems, flexibility, willingness to share with others, reflective in mathematical activities (doing the math).

RME has five characteristics (de Lange, 1987, 1996; Treffers, 1991; Gravimeijer, 1994 in Chotimah, 2014): (1) using contextual problems (contextual problems as applications and as a starting point from where the desired mathematics can appear); (2) using models or bridges with vertical instruments (attention is directed at developing models, schemes and symbolization rather than directly transferring formulas or formal mathematics directly); (3) using Student Contribution (a large contribution to the teaching and learning process is expected from the construction of students themselves who direct them from their informal methods towards more formal or standard); (4) interactivity (negotiating explicitly, intervening, cooperating and evaluating fellow students and teachers is an important factor in the constructive learning process where informal student strategies are used as the heart to achieve the formal); (5) integrated with other learning topics (a holistic approach, showing that learning units cannot be achieved separately but linkages and integration must be exploited in problem-solving)

Said Chotimah, Bernard, and Wulandari (2018) that VBA can help language learning (Visual Basic application for Excel) Visual Basic for Excel application, which is a programming language that gives the commands needed in Microsoft Excel to speed up operations automatically. In accordance with Winarno (Chotimah, Bernard, and Wulandari, 2018) who say that VBA (Visual Basic Application) or macro is a function and program commands in MS Office (including Excel) stored in the old Visual Basic, or Visual Basic before .NET framework version present. With VBA, work in Office can be optimized. Microsoft Excel is often used by most people in numerical processing because it has many mathematical functions that can be related to statistics, economics, engineering, and others. Not limited to that, but VBA in Excel benefits more from its use. As for the use of props that use VBA in Excel first, images can be interactive images, students become active and fun to learn mathematics because students understand more than without using ICT, the second does not cost much to make property, and third, that use Microsoft Excel software can be accessed by computer user. 


\section{Research Method}

This study was designed in experimental form with a pretest-posttest control design that aims to examine the role of the RME approach to the understanding and communication abilities and mathematical dispositions of elementary students. The students' mathematical comprehension and communication ability tests are compiled based on the characteristics of mathematical understanding and communication abilities and guidelines for good test preparation. Similarly, the preparation of students 'mathematical disposition instruments is arranged based on indicators on students' mathematical dispositions.

Thus the research design according to Ruseffendi (2005):

$$
\begin{array}{lll}
\text { A }: & 0 & \text { X } \\
\text { A }: & 0 & 0 \\
\text { Information: } \\
\text { A: random sample class selection } \\
0 \text { : initial test = final test (ability test } \\
\text { mathematical understanding and } \\
\text { communication) } \\
\text { X: treatment with the RME approach }
\end{array}
$$

Data will be analyzed using the statistical test $\mathrm{t}$ and test with statistics $\chi^{2}$ (to test associations between variables). The population in this study were all third-grade elementary school students in West Bandung Regency, while the sample was third-grade students from one elementary school that was purposively assigned to an elementary school in West Bandung Regency.

\section{Result and Discussion}

The first research was carried out by observing grade 3 elementary schools to observe the ability of students to understand mathematics. The researchers prepared the initial research instrument as a measure of students' ability to master mathematics, the results obtained by students can provide a meaningful response that is the relationship between the questions of the questions. In this stage, students have not been able to master multiplication operations because they do not understand the true meaning of multiplication. And assume that multiplication operations are the same as the sum.

From the results of the recapitulation of the students' values at the beginning of the observation, the average and standard deviation values of the two materials were obtained, namely mastery of the material about angles and material about the circumference of the flat building, which can be seen in table 1 .

It is alleged that there is a significant difference from the average mastery angle angle with flat plane mastery, where the average mastery angle is 6.89 higher than the average mastery of the flat plane with a value of 4.55 . Thus from the distribution of student data to the average value where the standard deviation mastery of angles is 3.18 and the circumference of the mastery standard is 3.57 , it means that the mastery of the angle is closer to the average value compared to the mastery of the flat plane. better than mastering the flat plane so that the problem is how students are able to understand the perimeter and the width of the plane. 
Table 1. Average and Standard Deviation

\begin{tabular}{ll}
\hline average (angle) & average circumference \\
\hline 6,888888889 & 4,555555556 \\
standard deviation & standard deviation \\
3,179797338 & 3,574601765 \\
\hline
\end{tabular}

\subsection{Students' Understanding Ability by Using the Concept of Images}

In order for students to understand the integer multiplication operation, students are given an explanation of the concept of the picture of broad material and the flat plane around using the drawing concept Visual Basic Application for Excel so that students calculate many objects related to addition operations and multiplication operations that later have broad relationships and traveling. After understanding the picture students in grade 3 are given the opportunity to try based on the concept of the picture. The following correlation of picture concepts and area and circumference values are shown in Table 2.

Table 2. Correlation of Picture Concepts and Area Value and traveling

\begin{tabular}{|c|c|c|c|}
\hline & & Opinion & Value \\
\hline \multirow[t]{4}{*}{ Picture } & Person Correlation & & \\
\hline & Sig. (2-tailed) & 1 &, $703 * *$ \\
\hline & $\mathrm{N}$ & &, 001 \\
\hline & & 20 & 20 \\
\hline \multirow[t]{4}{*}{ Value } & Person Correlation & 1 & \\
\hline & Sig. (2-tailed) & &, $703 * *$ \\
\hline & $\mathrm{N}$ & ,001 & \\
\hline & & 20 & 20 \\
\hline
\end{tabular}

**Correlation in significant at the 0.01 level (2-tiled)

Judging from the value of Pearson correlation 0.703 is a strong relationship between the ability to understand the concept of images with the results of student values. And seen from sig $0.001<0.05$ shows that the relationship between the ability of mathematical comprehension to use with images of student learning outcomes is significant.

\subsection{Students' Understanding Ability by Calculating}

This concept connects the process of students' understanding ability from the form of questions that are processed that are connected with the results of numbers. To understand it students must be assisted by researchers to get results. The following correlation between how to calculate with results is shown in Table 3.

Table 3. Correlation between How to Count with Results

\begin{tabular}{llrr}
\hline & Opinion & Value \\
\hline Count & Person Correlation & & \\
& Sig. (2-tailed) & 1 &, $810^{* *}$ \\
& N & &, 000
\end{tabular}




\begin{tabular}{llrr} 
& & 20 & 20 \\
Value & Person Correlation &, $810^{* *}$ & 1 \\
& Sig. (2-tailed) & 000 & \\
N & 20 & 20 \\
\hline
\end{tabular}

**Correlation in significant at the 0.01 level (2-tiled)

Judging from the value of Pearson correlation 0.810 is a very strong relationship between the ability of mathematical understanding of how to calculate student learning outcomes. And seen from sig 0,000<0,05 shows that the relationship between the ability of mathematical understanding using the method of calculating student learning outcomes is stronger. From table 5, the results of the calculation method with the results that below the average number of students there are 13 students or $65 \%$ of all students while for 7 students above the average value or $35 \%$ of students have understood the concept of counting.

\subsection{Student Understanding Ability with Definition}

Table 4. Correlation of the Picture Concept with Results With Control Count

\begin{tabular}{llrr}
\hline & & Count & \multicolumn{1}{c}{ Value } \\
\hline Definiti & Person Correlation & & \\
on & Sig. (2-tailed) & 1 &, 508 \\
& N & &, 808 \\
& & 20 & 20 \\
Value & Person Correlation & & \\
& Sig. (2-tailed) &, 058 & 1 \\
& N &, 808 & \\
& & 20 & 20 \\
\hline
\end{tabular}

**Correlation in significant at the 0.01 level (2-tiled)

Judging from the value of Pearson 0.058 correlation is a very weak strong relationship between the ability of mathematical understanding of the definition of student learning outcomes. And seen from sig 0.808>0.05 shows that the relationship between the ability of mathematical understanding of the definition of learning outcomes of weaker students is not significant.

\subsection{Ability to Understand Students with the Concept of Images with Learning Outcomes}

From the data above, there is a relationship between increasing Mathematics Learning with the RME Approach and assisting with ICT (Visual Basic Application for Excel) by understanding pictures and calculations while understanding the denominator with mathematics learning has nothing to do. And how much influence the improvement of mathematics learning by two factors can be seen from the regression, the following Table 5.

Table 5. Correlation of Picture Concepts to Results By controlling how to count

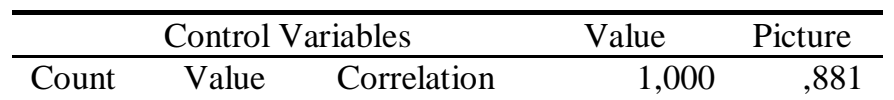




\begin{tabular}{llrr} 
& Sig. (2-tailed) & &, 000 \\
& df & & 17 \\
Picture & Correlation &, 881 & \\
& Sig. (2-tailed) &, 000 & 1 \\
& df & \multicolumn{1}{c}{17} & 17 \\
\hline & $* *$ Correlation in significant at the 0.01 level (2-tiled)
\end{tabular}

Judging from the correlation value of 0.881 , it is said that there is a very strong relationship between the ability to understand with pictures with student learning outcomes provided the teacher controls learning how to count and sig values $0.000<0.05$ that stronger relationships are significant. When compared with student learning without controlling learning how to count to students who have a correlation value of 0.703 that controlling learning how to count is more influential to increase student value.

\subsection{Students' Understanding Ability by Calculating with Learning Outcomes with the Concept of Images}

To see the effect of the relationship between how to calculate the results by controlling the concept of images can be seen from Table 6 .

Table 6. Correlation of How to Count on Results By Controlling the Concept of Images

\begin{tabular}{lrlrr}
\hline & Control Variables & \multicolumn{1}{c}{ Value } & \multicolumn{1}{c}{ Count } \\
\hline Picture & Value & Correlation & 1,000 &, 747 \\
& & Sig. (2-tailed) &. &, 000 \\
& df & 0 & 17 \\
& Picture & Correlation &, 747 & 1,000 \\
& & Sig. (2-tailed) &, 000 &. \\
& df & 17 & 0 \\
\hline
\end{tabular}

**Correlation in significant at the 0.01 level (2-tiled)

Judging from the correlation value of 0.747 , it is said that there is a strong relationship between the ability to understand by counting with student learning outcomes as long as the teacher controls the understanding of images and sig values of $0.000<0.05$ that the relationship between them is significant. When compared with student learning without controlling with understanding of images to students whose correlation value is 0.81 is more influential than controlling the understanding of images.

\subsection{The Influence of Picture Concepts and Ways to Calculate Learning Outcomes achieved}

This section addresses information to show the variables to be analyzed. The data uses the "Enter" method. There are several other methods besides this method, namely Stepwise, Backward, Forward and Remove. 
Table 7. Variables in How to Calculate and Concept The image analyzed

\begin{tabular}{|c|c|c|c|c|}
\hline \multicolumn{3}{|c|}{ Control Variables } & \multirow{2}{*}{$\begin{array}{l}\text { Value } \\
1,000\end{array}$} & \multirow{2}{*}{$\begin{array}{r}\text { Count } \\
747\end{array}$} \\
\hline Picture & Value & Correlation & & \\
\hline & & Sig. (2-tailed) & &, 000 \\
\hline & & $\mathrm{df}$ & 0 & 17 \\
\hline & Picture & Correlation & ,747 & 1,000 \\
\hline & & Sig. (2-tailed) & 000 & \\
\hline & & df & 17 & 0 \\
\hline
\end{tabular}

a. Dependent Variable: Value

b. All requested variables entered

Table 8. Determination Coefficients

\begin{tabular}{|c|c|c|c|c|c|}
\hline Model & $\bar{R}$ & R Square & $\begin{array}{l}\text { Adjusted } \\
\text { R Square }\end{array}$ & $\begin{array}{l}\text { Std.Error } \\
\text { of the } \\
\text { Estimate }\end{array}$ & $\begin{array}{l}\text { Durbin- } \\
\text { Watson }\end{array}$ \\
\hline 1 & .881 & .777 & .750 & 1.523 & 1.473 \\
\hline
\end{tabular}

From the value of the correlation between the ability to understand images and the ability to understand how to count students towards student learning outcomes is 0.881 means that the relationship between independent and dependent variables is very strong, and the coefficient of determination 0.777 or $77.77 \%$ means that the increase in student learning outcomes can be explained by variables of understanding ability picture and ability to count. While $22.23 \%$ must be explained from other factors. For the value of Durbin Watson 1,473 means not less than 1 or more than 3 it can be concluded that there is no arrhythmic autocorrelation, there is no independent variable that interferes with the independent variable with the dependent variable or the ability to understand the picture will not interfere with the relationship of the variable ability to understand how to count with student learning outcomes Likewise, the variable ability to understand how to count does not interfere with the ability to understand images with student learning outcomes.

Table 9. Anova Test

\begin{tabular}{llrrrrr}
\hline Model & $\begin{array}{l}\text { Sum of } \\
\text { Squares }\end{array}$ & df & $\begin{array}{l}\text { Mean } \\
\text { Square }\end{array}$ & F & Sig. \\
\hline 1 & Regressi & 137.128 & & 2 & 68,564 & 29,567 \\
& on & & & & & \\
& Residual & 39,422 & & 17 & 2,319 & \\
& Sum & 176,550 & 19 & & & \\
\hline
\end{tabular}

a. Dependent Variable: Value

b. Predictors: (Constant), Count, Picture 
ANOVA test produces $\mathrm{F}$ value is 29,567 with a level of $0,000 \mathrm{sig}<0,05$, which means that this regression model is feasible to be used to predict student learning outcomes. To see whether ANOVA really shows the feasibility of predicting student learning outcomes can be seen from the following steps.

The first stage:

$\mathrm{H}_{0}$ : Ability to understand pictures and how to count does not affect student learning outcomes

$\mathrm{H}_{1}$ : Ability to understand pictures and how to count affect

student learning outcomes.

Second Stage:

Calculate $\mathrm{F}$ table value with 0.05 sig and variable degree of freedom degree $1=3-1=2$ and

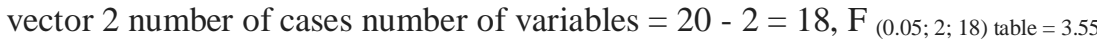

Third phase:

Determine the following criteria

$\mathrm{H}_{0}$ is accepted and $\mathrm{H}_{1}$ is rejected if $\mathrm{F}_{\text {table }}>\mathrm{F}_{\text {hitung }}$

$\mathrm{H}_{1}$ is accepted and $\mathrm{H}_{0}$ is rejected if table $<\mathrm{F}$ count

Table 10. The Coefficient of the Concept of Images and How to Calculate

\begin{tabular}{llrrrrr}
\hline \multirow{2}{*}{ Model } & \multicolumn{2}{c}{$\begin{array}{c}\text { Unstandardized } \\
\text { Coefficient }\end{array}$} & Standardized Coefficient & t & \multirow{2}{*}{ Sig. } \\
\hline \multirow{3}{*}{1} & & B & Std. Error & Beta & & \\
& (Constant) &, 585 & 1,533 & &, 382 &, 708 \\
& Picture & 1,392 &, 181 & 1,052 & 7,673 &, 000 \\
& Count & 2,006 &, 433 &, 636 & 4,638 &, 000 \\
\hline
\end{tabular}

a. Dependent Variable: Value

Fourth Stage:

Make a decision, it is known that $\mathrm{F}_{\text {count }}=29.567$ while $\quad \mathrm{F}_{\text {tabel }}=3.55$ is concluded that $\mathrm{F}$ count $>\mathrm{F}$ tabel means that $\mathrm{H}_{0}$ is rejected and $\mathrm{H}_{1}$ is accepted means the Ability to Understand the Picture and How to Calculate have an effect on Student Learning Outcomes.

For the constant absence of the influence of mathematics learning from sig $0.708>0.05$ while for the image has sig $0.000<0.05$ has an influence on mathematics learning as well as for how to calculate with sig $0,000<0,05$ has an influence on mathematics learning. so that obtained linear regression $\mathrm{y}=1.392 \mathrm{x}_{1}+2.006 \mathrm{x}_{2}+0.585$, if we see the coefficient of the variable that how to calculate more influence than understand the picture. 
Information:

$\mathrm{Y}=$ Student Learning Outcomes

$\mathrm{X}_{1}=$ Picture Understanding Ability

$\mathrm{X}=$ Understanding Ability to Calculate

$\mathrm{B}_{1}$ is a coefficient of Understanding Ability Picture of 1.392 meaning that if $X_{1}$ is included in the value of 1 then the Student Learning Outcomes will increase by 1.392. And $\mathrm{B}_{2}$ is the coefficient of the ability to understand how to calculate the amount of 2.006 means that if $X_{2}$ is included in the value 1 then the student learning outcomes will increase by 2.006 . To test whether the regression coefficient is significant or not, can be seen from the following stages:

The first stage:

$\mathrm{H}_{0}$ : Significant Regression Coefficient

$\mathrm{H}_{1}$ : Significant Regresu Coefficient

Second stage:

Calculate $\mathrm{t}$ table with sig $0.05 / 2=0.025$ with degrees of freedom $20-2=18 \cdot t_{0,025,18}=2,1$

Third phase:

$\mathrm{H}_{0}$ is accepted and $\mathrm{H}_{1}$ is rejected if $\mathrm{t}_{\text {table }}>\mathrm{t}$ count

$\mathrm{H}_{0}$ is rejected and $\mathrm{H}_{1}$ is accepted if the table is $<\mathrm{t}$ count

Table 11. Prediction of student learning improvement

\begin{tabular}{|c|c|c|c|c|c|}
\hline & Minimum & Maximum & Mean & $\begin{array}{l}\text { Std. } \\
\text { Deviation }\end{array}$ & $\mathrm{N}$ \\
\hline $\begin{array}{l}\text { Predicated } \\
\text { Value }\end{array}$ & 4,60 & 14,95 & 9,65 & 2,686 & 20 \\
\hline $\begin{array}{l}\text { Residual } \\
\text { Std. }\end{array}$ & $-1,609$ & 3,000 & ,000 & 1,440 & 20 \\
\hline $\begin{array}{l}\text { Predicted } \\
\text { Value }\end{array}$ & $-1,881$ & 1,974 & ,000 & 1,000 & 20 \\
\hline $\begin{array}{l}\text { Std. } \\
\text { Residual }\end{array}$ & $-1,056$ & 1,970 & ,000 & ,0946 & 20 \\
\hline
\end{tabular}

a. Dependent Variable: Value

Fourth Stage:

Making

decision, t_hiutng for the Comprehension Ability Coefficient Figure 7.763 and the Coefficient of Pamahaman Ability How to Calculate 4.638, it turns out that the two coefficients greater than $\mathrm{t}$ table $=2.1$ means that $\mathrm{H}_{0}$ is rejected and $\mathrm{H}_{1}$ is accepted it can be concluded that the two regression coefficients are significant.

\section{Conclusion}

Learning uses realistic mathematics education with the help of VBA for Microsoft Excel rather than learning before using the approach and assisted by ICT. Learning uses realistic mathematics education with the help of VBA for Microsoft Excel rather than learning before using the approach and assisted by ICT. Using the Realistic Mathematics Education approach influences the improvement of comprehension and communication skills depending on the concept of the picture and the method of calculating elementary school students. 


\section{Acknowledgments}

We thank the Chancellor and the Vice Chancellors of the University Sarjanawiyata Tamansiswa and their staff and the entire international seminar committee who have been pleased to give us the opportunity to work. Hopefully Sarjanawiyata Tamansiswa University will progress.

\section{References}

[1] Amelia, R. (2015). Pencapaikan Kemampuan Komunikasi dan Disposisi Matematis Siswa dengan Menggunakan Metode Pembelajaran Inkuiri Terbimbing. Prosiding Seminar Nasional Matematika dan Pendidikan Matematika STKIP Siliwangi Bandung. Vol.3, No.1. (181-187).

[2] BNSP (2006). Standar Isi untuk Satuan Pendidikan Dasar dan Menengah. Dokumen BNSP: Jakarta.

[3] Chotimah, S., Bernard, M., \& Wulandari, S. M. (2018, January). Contextual approach using VBA learning media to improve students' mathematical displacement and disposition ability. In Journal of Physics: Conference Series (Vol. 948, No. 1, p. 012025). IOP Publishing.

[4] Chotimah, S. (2015). Upaya Meningkatkan Kemampuan Komunikasi Matematik Siswa SMP di Kota Bandung dengan Pendekatan Realistic Mathematics Educations pada Siswa SMP di Kota Bandung. Didaktik, 9(1), 26-32.

[5] Hendriana, H., Soemarmo, U. (2014). Penilaian Pembelajaran Matematika. Refika Aditama: Bandung.

[6] Herlina, S., Turmudi, Dahlan, JA. (2012). Efektivitas Strategi React dalam Upaya Peningkatan Kemampuan Komunikasi Matematis Siswa Sekolah Menengah Pertama. Jurnal Pengajaran MIPA.17, (1) 1-7.

[7] Kilpatrick, J., Swafford, J., \& Clarck, R.E. (2001). Adding it up: Helping Children Learn Mathematics. Washington, DC: National Academy Press.

[8] NCTM. (2000). Principles and Standards for School Mathematics. Reston, VA: NCTM.

[9] Ruseffendi, H.E.T. (2005). Dasar-Dasar Penelitian dan Bidang Non-Eksakta lainnya. Bandung: Tarsito

[10] Suherman (2003). Strategi Pembelajaran Kontemporer. Bandung: UPI.

[11] Wardani, S. (2009). Meningkatkan Kemampuan Berpikir Kreatif dan Disposisi Matematik Siswa SMA melalui Pembelajaran dengan Pendekatan Model Sylver. Disertasi UPI. Bandung: Tidak Diterbitkan. 